\title{
Effect of alfalfa silage storage structure and rumen-protected methionine on production in lactating dairy cows ${ }^{1}$
}

\author{
G. A. Broderick ${ }^{2}$ and R. E. Muck \\ Agricultural Research Service, USDA, US Dairy Forage Research Center, 1925 Linden Drive West, Madison, WI 53706
}

\begin{abstract}
The objective of this study was to determine whether production and nutrient utilization differed when lactating cows were fed diets based on 1 of 3 sources of alfalfa silage (AS) and whether performance was altered by feeding rumen-protected Met (RPM; fed as Mepron). Thirty-six lactating Holstein cows were blocked by parity and days in milk, then assigned to a randomized complete block design and fed a $3 \times 2$ arrangement of diets formulated from alfalfa ensiled in bag, bunker, or oxygen-limited silos, and supplemented with either 0 or $8 \mathrm{~g}$ of RPM/d. After feeding a covariate diet for $3 \mathrm{wk}$, treatment diets were fed for the remaining $12 \mathrm{wk}$ of the trial. Experimental diets averaged [dry matter (DM) basis] $41 \%$ AS, $24 \%$ corn silage, $24 \%$ high-moisture corn, $3.7 \%$ soybean meal, $4 \%$ roasted soybeans, $2 \%$ ground shelled corn, $1.0 \%$ minerals and vitamins, $16.7 \% \mathrm{CP}$, and $31 \%$ NDF. Alfalfa from the oxygen-limited silo was lower in ash, higher in lactate, nonfiber carbohydrate, and in vitro NDF digestibility, had lower $\mathrm{pH}$ and ammonia content, and gave rise to greater DM intake and ADF digestibility than silage from the other 2 silos, indicating a more effective fermentation that, in turn, resulted in greater nutrient preservation. However, the more favorable composition, intake, and digestibility of alfalfa from the oxygen-limited silo were not reflected in improved milk production, which was not different among alfalfa sources. There was increased apparent N efficiency and trends for improved feed efficiency and protein yield with RPM supplementation across all 3 silages. The National Research Council (2001) model predicted that feeding RPM reduced Lys:Met ratio from 3.5 to 2.9 , indicating that the diets were limiting in Met.
\end{abstract}

\footnotetext{
Received April 25, 2008

Accepted November 6, 2008.

${ }^{1}$ Mention of any trademark or proprietary product in this paper does not constitute a guarantee or warranty of the product by the USDA or the Agricultural Research Service and does not imply its approval to the exclusion of other products that also may be suitable.

${ }^{2}$ Corresponding author: glen.broderick@ars.usda.gov
}

Key words: alfalfa silage storage structure, rumenprotected methionine, milk yield, nitrogen efficiency

\section{INTRODUCTION}

The conditions under which alfalfa is harvested and ensiled affect the quality of the silage and utilization of its nutrients by lactating dairy cows (Muck and O'Kiely, 2002). The protein in alfalfa silage (AS) is particularly problematic, being subject to extensive degradation to NPN in the silo. We have observed NPN contents in AS that range from $43 \%$ (Nagel and Broderick, 1992) to as much as $87 \%$ (Muck, 1987) of total CP equivalent. The NPN in AS is rapidly degraded to ammonia in the rumen and, if not captured as microbial protein, will end up largely as urea-N excreted in the urine. Improvements in milk and protein yield with diets based on AS have been achieved by replacing solvent-extracted soybean meal with heat-treated soy protein sources that are higher in RUP (Broderick et al., 1990; Faldet and Satter, 1991), and by feeding fishmeal (Broderick, 1992) and canola meal (Brito and Broderick, 2007), both of which supply RUP that is high in Met and Cys. Moreover, other research showed that supplementing diets containing about 20\% AS with rumen-protected Met (RPM) improved yields of milk, fat, and protein in 2 of 3 Latin square experiments (Broderick et al., $2008,2009)$. These results indicated that milk production could be improved on AS diets by increasing the supply of MP or the limiting essential AA. In another reversal trial, we found that fiber digestion and yield of fat and FCM were greater when cows were fed alfalfa ensiled in an oxygen-limited silo versus bag and bunker silos (Krizsan et al., 2007). We speculated that RPM might be more effective when supplementing forages with greater energy availability.

A trial was conducted to study the effects on production and nutrient utilization of adding RPM as Mepron (Degussa Corp., Kennesaw, GA) to diets with differing sources of AS. In our previous work, we tested these variables in reversal trials where lactating cows were switched among dietary treatments every $4 \mathrm{wk}$. The objective of the current trial was to determine whether feeding alfalfa ensiled in bag, bunker, or oxygen-limited 
Table 1. Chemical composition of ensiled forage and alfalfa silages stored in different structures

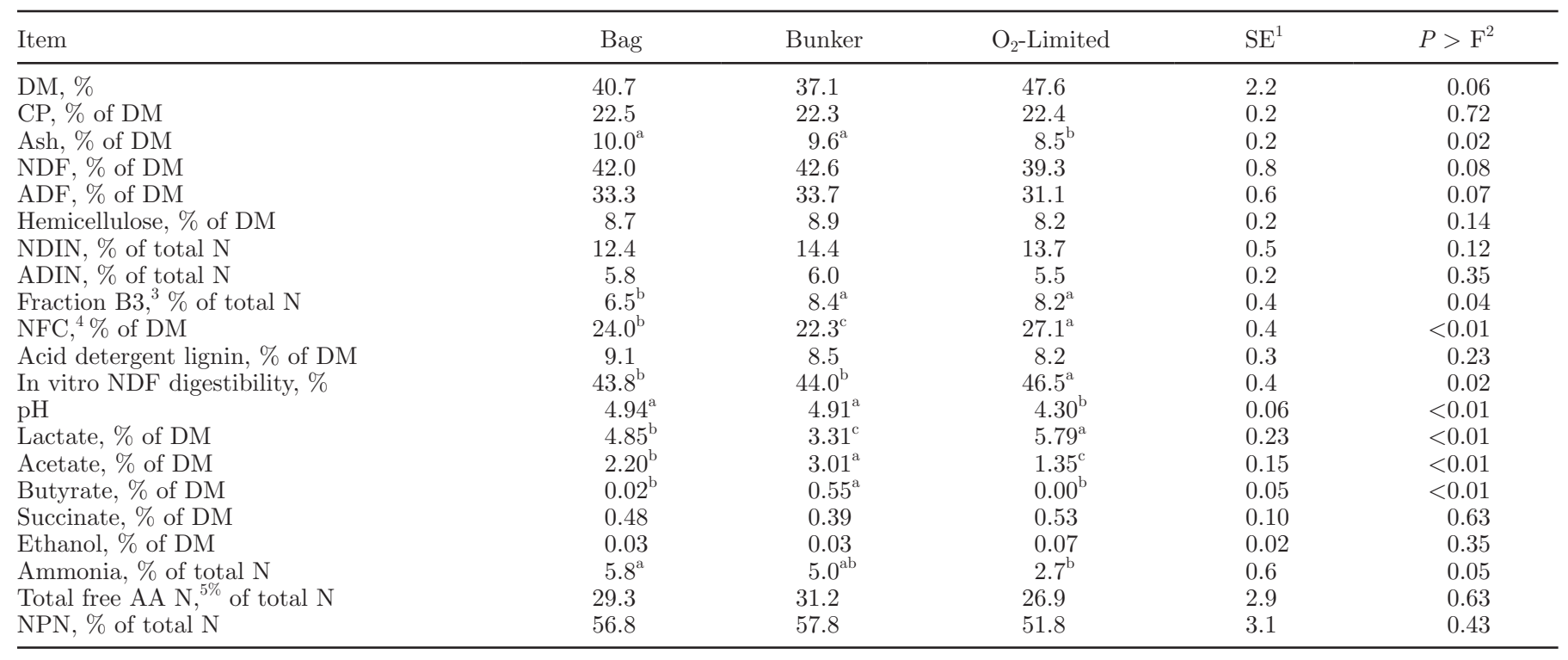

${ }^{\mathrm{a}-\mathrm{c}}$ Means for the 3 silages with different superscripts are different $(P<0.05)$.

${ }^{1}$ Standard error of the mean.

${ }^{2}$ Probability of significant effect of structure used to ensiled alfalfa silage.

${ }^{3}$ Fraction B3 = NDIN (\% of total N) - ADIN (\% of total N) (Sniffen et al., 1992).

${ }^{4} \mathrm{NFC}=100-(\% \mathrm{NDF}-\mathrm{NDIN} \times 6.25)-\% \mathrm{CP}-\%$ fat $-\%$ ash, using the tabular value for fat content of immature legume silage $(2.3 \%$ of DM; NRC, 2001).

${ }^{5}$ Total free AA $\mathrm{N}=$ total free AA, $\mathrm{mmol} \times(40.3 \mathrm{mg}$ of $\mathrm{N} / \mathrm{mmol}$ of total free AA) (Broderick, 1987).

silos, with or without supplemental RPM, would improve milk production and nutrient utilization under a normal feeding regimen where animals remained on their diets throughout the experimental period.

\section{MATERIALS AND METHODS}

\section{Ensiling of Alfalfa}

Alfalfa from the same 4 fields was ensiled in 3 different silos: bag (AgBag Systems Inc., St. Nazianz, WI), bunker, or oxygen-limited tower silo (Harvestore, Engineered Storage Products Company, DeKalb, IL). Dimensions of the bag, bunker, and oxygen-limited silos were, respectively, $2.4 \mathrm{~m}$ diameter $\times$ approximately $52 \mathrm{~m}$ long, $4.9 \mathrm{~m}$ wide $\times 22 \mathrm{~m}$ long $\times 3.6 \mathrm{~m}$ high, and $4.3 \mathrm{~m}$ diameter $\times 15 \mathrm{~m}$ high. First-cutting alfalfa was harvested over a 2-d period in May 2005 to produce regrowth of similar maturity across a total area of 82.4 ha. The second-cutting alfalfa was mown June 26 to 27, 2005, using a New Holland FX 58 forage harvester (CNH Global, New Holland, PA) and field-wilted for an average of $24 \mathrm{~h}$. A portion of each field was allotted to each silo. On June 27 to 28, 2005, alfalfa was chopped to a theoretical length of $2.9 \mathrm{~cm}$ and filled without additives into the silos. On both dates, 2 out of 4 windrows were chopped and ensiled into the bunker and 1 out 4 windrows was chopped and ensiled into the bag. The last of the 4 windrows was chopped and ensiled into the oxygen-limited silo only on June 28 . The target DM ranges for ensiled forage were 30 to $40 \%$ (bag and bunker) and 45 to $55 \%$ (oxygen-limited), as is recommended for these structures (Muck and Kung, 2007). Drying conditions were good and no rainfall was recorded during harvest. All AS was weighed and sampled as ensiled and when fed out from each silo during the feeding study. Total DM losses in the silos were estimated as gaseous losses plus spoiled silage that was not fed. Gaseous losses were computed from the ratio of the total amount of DM removed (fed plus spoiled) to total amount of DM used to fill each silo. Silage densities in bag and bunker silos, calculated from the total amount filled and silo dimensions, were 197 and $293 \mathrm{~kg}$ of $\mathrm{DM} / \mathrm{m}^{3}$, respectively. Composition data for the $3 \mathrm{AS}$ sources are in Table 1.

\section{Feeding Study}

Twenty-four multiparous Holstein cows averaging (mean $\pm \mathrm{SD}$ ) parity $2.7 \pm 0.9,51 \pm 5 \mathrm{~kg}$ of milk/d, 130 $\pm 42 \mathrm{DIM}$, and $652 \pm 38 \mathrm{~kg}$ of BW, and 12 primiparous Holstein cows averaging $42 \pm 2 \mathrm{~kg}$ of milk/d, $135 \pm$ $28 \mathrm{DIM}$, and $566 \pm 21 \mathrm{~kg}$ of $\mathrm{BW}$, were grouped by parity and DIM into 6 blocks of 6 cows for use in a 
trial of randomized complete block design. Cows were all fed the same standard diet for a covariate period 3 wk in length, beginning June 1, 2006. The covariate diet was fed as a TMR and contained (DM basis): $40 \%$ of a standard AS, 20\% rolled corn silage, 29\% highmoisture shelled corn, $4 \%$ solvent-extracted soybean meal, $4 \%$ roasted soybeans, $2 \%$ ground shelled corn, $0.5 \%$ sodium bicarbonate, $0.3 \%$ salt, $0.1 \%$ dicalcium phosphate, $0.12 \%$ vitamins-mineral supplement (about the same as that fed in the 6 experimental diets), $17.2 \%$ $\mathrm{CP}$, and $29 \% \mathrm{NDF}$. After the covariate period, cows in each block were randomly assigned to 1 of 6 dietary treatments in a $3 \times 2$ arrangement: diets containing 1 of the $3 \mathrm{AS}$, supplemented with either 0 or $9 \mathrm{~g} / \mathrm{d}$ of RPM fed as $0.06 \%$ Mepron in the DM, assuming an intake of $25 \mathrm{~kg}$ of $\mathrm{DM} / \mathrm{d}$ and an equivalence of $0.6 \mathrm{~g}$ of metabolizable Met/g of Mepron (Berthiaume et al., 2001). Actual DM intake during the trial was lower and metabolizable Met/g supply from RPM averaged about $8 \mathrm{~g} / \mathrm{d}$. Diets were prepared as TMR by blending individual feed ingredients plus a premix composed of ground shelled corn, minerals, and vitamins, with or without Mepron; premix was added to the TMR at $3.0 \%$ of the DM. Cows were fed the same experimental diet continually throughout the remaining $12 \mathrm{wk}$ of this study (from June 22 to September 14, 2006). Beginning at about 60 DIM, all cows were injected once every 2 wk with bST (500 mg of Posilac; Monsanto, St. Louis, $\mathrm{MO})$. Starting 2 wk before the trial, bST injections were synchronized such that, beginning on $\mathrm{d} 1$ of the covariate period and at 14-d intervals thereafter, injections were continued until completion of the study. Cows were housed in tie stalls and had free access to water throughout the experiment. Care and handling of the animals was conducted as outlined by the guidelines of the University of Wisconsin institutional animal care and use committee.

Diets were offered once daily at $1000 \mathrm{~h}$ after orts were collected daily at $0900 \mathrm{~h}$. Amounts of feed offered were adjusted daily to allow refusals equal to 5 to $10 \%$ of intake. Daily samples of approximately $0.5 \mathrm{~kg}$ of each silage, the high-moisture shelled corn, and each TMR and orts were collected, stored at $-20^{\circ} \mathrm{C}$, and used to make weekly composites. Weekly samples of soybean meal, roasted soybeans, and premixes were also taken.

Dry matter contents of samples of weekly composites and individual feed samples were determined by drying at $60^{\circ} \mathrm{C}$ (forced-air oven) for $48 \mathrm{~h}$. The $60^{\circ} \mathrm{C}$ DM contents of dietary ingredients were used weekly to adjust as-fed compositions of the TMR. Dry matter intake was computed based on the $60^{\circ} \mathrm{C}$ DM contents of the TMR and orts. These samples were ground to pass a 1-mm Wiley mill screen (Arthur H. Thomas, Philadelphia, PA) and analyzed later for total N (Leco FP-2000
Nitrogen Analyzer, Leco Instruments Inc., St. Joseph, MI), absolute DM, ash, and OM (AOAC, 1980), sequentially (Van Soest et al., 1991) for NDF, ADF, and acid detergent insoluble $\mathrm{N}$ using heat-stable $\alpha$-amylase and $\mathrm{Na}_{2} \mathrm{SO}_{3}$ (Hintz et al., 1995), and also for neutral detergent insoluble $\mathrm{N}$ without use of $\mathrm{Na}_{2} \mathrm{SO}_{3}$ (Licitra et al., 1996). Silage extracts were prepared in distilled water from weekly composites according to Muck (1987), pH determined immediately, and extracts were analyzed for ammonia and total free AA (Broderick et al., 2004) using flow-injection (Lachat Quik-Chem 8000 FIA, Lachat Instruments, Milwaukee, WI), for NPN (Muck, 1987; VarioMax CN, Elementar Analysensystem GmbH, Hanau, Germany), and for organic acids and ethanol (Muck and Dickerson, 1988; Krizsan et al., 2007). Dried AS samples were also analyzed for ruminal in vitro NDF digestibility (Goering and Van Soest, 1970). Weekly TMR composites were analyzed for indigestible ADF (ADF remaining after $12 \mathrm{~d}$ of in situ incubation; Huhtanen et al., 1994). The TMR composites also were analyzed for total fat (method 920.39, AOAC, 1997; Dairyland Laboratories, Arcadia, WI), starch (Hall et al., 1999; T. K. M. Webster, West Virginia Univ., Morgantown), and neutral detergent insoluble N (NDIN; Van Soest et al., 1991; Hintz et al., 1995) to compute NFC. Compositions of the 3 AS are in Table 1 and that of the diets are in Table 2.

Cows were milked twice daily and milk yield was recorded at each milking throughout the covariate and experimental periods. Milk samples from both the a.m. and p.m. milking were collected on $\mathrm{d} 11$ and 18 of the covariate period and d 11, 25,39,53,67, and 81 of the experimental period. At collection, all milk samples were preserved with 2-bromo-2-nitropropane-1,3-diol. Individual a.m. and p.m. samples were analyzed for fat, true protein, lactose, and SNF by infrared analysis (AgSource, Verona, WI) with a Foss FT6000 (Foss North America Inc., Eden Prairie, MN) using AOAC (1990; method 972.16). For MUN determination, $5 \mathrm{~mL}$ of milk sample from each milking was treated with 5 $\mathrm{mL}$ of $25 \%$ (wt/vol) TCA. Samples were vortexed and allowed to stand for $30 \mathrm{~min}$ at room temperature before filtering through Whatman \#1 filter paper. Filtrates were stored at $-20^{\circ} \mathrm{C}$ until MUN analysis by an automated colorimetric assay (Broderick and Clayton, 1997) adapted to flow-injection (Lachat Quik-Chem 8000 FIA). Concentrations and yields of fat, true protein, lactose, and SNF, and MUN concentration were computed as the weighted means from a.m. and p.m. milk yields for each test day. Efficiency of conversion of feed DM was computed for each cow over the last 2 wk of the covariate period and for each 2-wk interval of the experimental period by dividing mean milk yield by mean DMI. 
Fecal grab samples were collected from all cows about $6 \mathrm{~h}$ prefeeding (a.m. sampling) and $6 \mathrm{~h}$ postfeeding (p.m. sampling) on d 25 to 26,53 to 54 , and 81 to 82 (wk 4, 8, and 12 of the experimental period). Fecal samples were transferred to aluminum pans and held at $60^{\circ} \mathrm{C}$ in a forced-air oven until completely dry. Fecal samples were then ground to pass a 1-mm Wiley mill screen, and a single composite was prepared for each cow for each of the 3 sampling times by mixing equal DM from both samples. Fecal samples were analyzed for DM, OM, NDF, ADF, total N, and indigestible $\mathrm{ADF}$ as described earlier. Indigestible ADF was used as an internal marker to estimate apparent nutrient digestibility and fecal $\mathrm{N}$ output (Cochran et al., 1986). At the times of fecal sampling, spot urine samples were obtained from all cows by mechanical stimulation of the vulva. After collection, $15 \mathrm{~mL}$ of urine was pipetted into specimen containers holding $60 \mathrm{~mL}$ of $0.072 \mathrm{~N} \mathrm{H}_{2} \mathrm{SO}_{4}$ and stored at $-20^{\circ} \mathrm{C}$ until analysis. After thawing at room temperature, urine samples were filtered through Whatman no. 1 filter paper; filtrates were analyzed for creatinine using a picric acid assay (Oser, 1965) adapted to flow-injection analysis (Lachat Quik-Chem 8000 FIA), for total N (Leco FP-2000 Nitrogen Analyzer) and for urea with the colorimetric method used for MUN. Daily urine volume and excretion of urea $\mathrm{N}$ and total $\mathrm{N}$ were estimated from urinary creatinine concentration assuming a creatinine excretion rate of 29 $\mathrm{mg} / \mathrm{kg}$ of BW (Valadares et al., 1999). Apparent efficiency of utilization of feed $\mathrm{N}$ (assuming no retention or

Table 2. Composition of diets containing alfalfa silage ensiled in 1 of 3 structures and containing 0 or $8 \mathrm{~g} / \mathrm{d}$ of rumen-protected Met $^{1}$

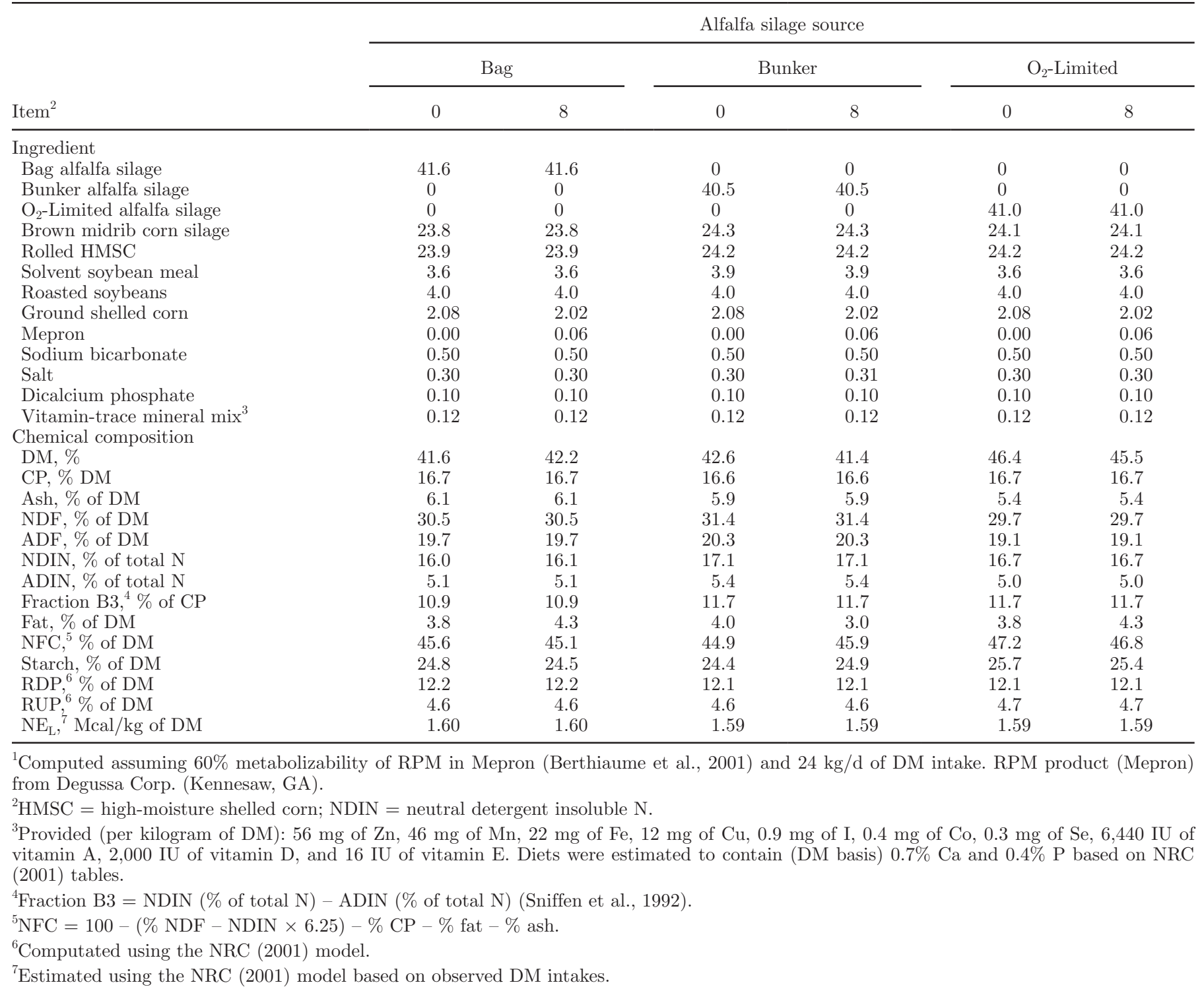


mobilization of body $\mathrm{N}$ ) was calculated for each cow by dividing mean milk $\mathrm{N}$ output (milk true protein/6.38) by mean $\mathrm{N}$ intake. Body weights were measured on the last $3 \mathrm{~d}$ of the covariate period and on d 26 to 28,54 to 56 , and 82 to 84 (wk 4, 8 , and 12 of the experimental period).

\section{Statistical Analysis}

Effect of AS source on composition traits was analyzed with the GLM (SAS Institute, 1999-2000) using a model that included silage and period, where a single mean was computed from individual weekly samples for each 4 -wk period ( $\mathrm{n}=3$ for each AS). Statistical analyses of all animal data except BW change, MUN, apparent digestibility, and excretion traits were conducted using the mixed procedures (SAS Institute, 1999-2000) using a model with an SP(POW) structure for repeated measures; the model included the covariate mean for each trait for each cow plus block, AS source, RPM level, and week, as well as the interactions silage $\times \mathrm{RPM}$, week $\times$ silage, week $\times \mathrm{RPM}$, and the 3 -way interaction week $\times$ silage $\times$ RPM. The same approach was used for BW change, MUN, apparent digestibility, and excretion traits except the model did not contain the covariate. All variables were considered fixed, except cow, whole-plot error, and subplot error, which were considered random. Interaction terms were removed from the model when $P \geq 0.25$. Least squares mean estimates for each of the 3 AS sources and for both levels of RPM are reported; separation of least squares was conducted at $\alpha=0.05$ using the PDIFF option in the LSMEANS statement. For all statistical analyses, significance was declared at $P \leq 0.05$ and trends at $P \leq 0.10$.

\section{RESULTS AND DISCUSSION}

\section{Silage Composition}

Average chemical compositions of the $3 \mathrm{AS}$ fed in this trial are in Table 1. Mean CP concentrations $>22 \%$ and mean NDF concentrations $\leq 43 \%$ of DM indicated that all $3 \mathrm{AS}$ were of good to high quality. As is usually observed, $>50 \%$ of total CP equivalent was found in NPN in all 3 silages (Broderick, 1995). Nevertheless, there were several composition differences among the silages. Alfalfa ensiled in the oxygen-limited structure was lower $(P \leq 0.05)$ in ash, $\mathrm{pH}$, ammonia-N, and acetate, and was higher $(P=0.01)$ in lactate and NFC with greater $(P=0.02)$ in vitro NDF digestibility than the other 2 AS. This indicated that fermentation was more effective in the oxygen-limited silo, resulting in better preservation of the organic matter and NFC originally present in the forage (Muck et al., 2003); this also suggested that energy availability on the diet formulated from that alfalfa would be greater. Butyrate, which may indicate presence of clostridial fermentation (McDonald et al., 1991), was found in bunker AS but was essentially zero in AS from bag and oxygen-limited silos. Previously, we found small amounts of butyrate only in alfalfa from the bunker silo but otherwise little difference in composition of AS ensiled in bag, bunker, and oxygen-limited structures (Krizsan et al., 2007); however, ensiled forage material was perhaps too dry, ranging from 47 to $49 \% \mathrm{DM}$ over the $3 \mathrm{AS}$ in that study. Silage from bunker and oxygen-limited silos also contained greater $(P=0.04)$ proportions of total $\mathrm{CP}$ in fraction B3 (NDIN - ADIN); more of this protein fraction may escape the rumen (Sniffen et al., 1992). Except for slightly higher content of lactate and NFC in AS from the bag, composition of alfalfa ensiled in bag and bunker silos was not different (Table 1). The DM contents of AS from the bag and oxygen-limited silos fell within target DM ranges of, respectively, 30 to $40 \%$ and 45 to $55 \%$; bunker silage was slightly above the target range of 30 to $40 \%$ DM (Muck and Kung, 2007).

\section{Effect of Silage Source on Production}

None of the interactions between silage source and RPM supplementation was significant $(P \geq 0.12)$, so these main effects will be considered separately. The 6 diets fed in this study averaged $41 \%$ AS and $16.7 \% \mathrm{CP}$ and were generally of similar composition; the major chemical difference was that diets based on alfalfa from the oxygen-limited silo contained slightly less NDF and ADF and slightly more NFC (Table 2). Compared with the other silages, cows fed that alfalfa also consumed more DM $(P<0.01)$, tended to have greater $\mathrm{DM}$ and organic matter digestibility, had higher ADF digestibility $(P=0.04)$, and were in relative positive $\mathrm{N}$ balance $(P=0.02$; Table 3$)$. The relative positive $\mathrm{N}$ balance derived from lower $(P<0.02)$ urinary urea $\mathrm{N}$ and total $\mathrm{N}$, which paralleled lower $(P<0.01)$ urine volume on the oxygen-limited AS. Moreover, total DM losses, estimated as spoiled silage and gaseous losses, were substantially lower for AS from the oxygen-limited structure than the other 2 silos; spoiled AS that was not fed and gaseous losses were, respectively, 0.2 and $10.2 \%$ (bag), 2.9 and $15.3 \%$ (bunker), and 0.0 and $1.5 \%$ ensiled DM (oxygen-limited). Approximate feed-out rates were 60,14 , and $5 \mathrm{~cm} / \mathrm{d}$ for, respectively, the bag, bunker, and oxygen-limited silos, and the feeding phase was conducted during summer months (from June 22 to September 14, 2006) when silage DM losses are most problematic. Moreover, this meant that all 3 
silages were stored for an average of 13 mo before being fed. The maximum temperature recorded during the trial was $36.7^{\circ} \mathrm{C}$; mean minimum and maximum daily temperatures over this period were 13.3 and $27.8^{\circ} \mathrm{C}$ (for zip code 53578; https://weather-warehouse.com). Elevated temperatures may account for the lower DM intake $($ mean $=22.1 \mathrm{~kg} / \mathrm{d})$ compared with the covariate period $($ mean $=25.8 \mathrm{~kg} / \mathrm{d})$, as well as our previous trial $($ mean $=24.1 \mathrm{~kg} / \mathrm{d})$, and may partly explain the reduction in milk yield from that before the study (mean = $47 \mathrm{~kg}$ milk/d) and the covariate period (mean $=44 \mathrm{~kg}$ milk/d).

Despite the greater intake of AS with more favorable chemical composition and digestibility, greater yield of milk or milk components was not observed. Because intake was greater but production was unchanged, feed efficiency (milk/DM intake) was lower $(P=0.02)$ on diets containing alfalfa from the oxygen-limited silo versus that ensiled in the bag silo, while the bunker AS was intermediate. Nor did the differences in DM intake result in an effect $(P=0.63)$ on $\mathrm{BW}$ change. Our previous reversal trial showed that, in cows averaging $40 \mathrm{~kg} / \mathrm{d}$ of $3.5 \% \mathrm{FCM}$, feeding alfalfa ensiled in an oxygen-limited structure resulted in greater yields of FCM and fat than feeding alfalfa ensiled in bag or bunker silos (Krizsan et al., 2007). We speculate that the cows in the present study, which were eating $2 \mathrm{~kg} / \mathrm{d}$ less $\mathrm{DM}$ and producing about $3 \mathrm{~kg} / \mathrm{d}$ less FCM, were unresponsive to the greater nutrient supply from the higher quality alfalfa ensiled in the oxygen-limited silo. It is also possible that use of a randomized complete block design, rather than a Latin square or other reversal design, was too insensitive to detect actual production differences among these silage treatments. Nevertheless, the lack of an effect of silage source is difficult to explain. Surprisingly, MUN appeared to be unrelated to urinary $\mathrm{N}$ excretion and apparent $\mathrm{N}$ balance in this experiment.

\section{Effect of RPM on Production}

Supplementation with RPM tended to improve feed efficiency and true protein yield, and gave rise to a 2-percentage-unit increase $(P=0.01)$ in $\mathrm{N}$ efficiency across diets formulated from all 3 sources of AS (Table 3 ). The improved conversion of dietary $\mathrm{CP}$ to milk protein suggested that the $40 \mathrm{~g} / \mathrm{d}$ greater yield of milk true protein was a real effect due to providing the limiting essential AA. A break-point analysis was used by NRC (2001) to estimate requirements for maximal milk protein concentration and yield of about $7.2 \%$ Lys and $2.4 \%$ Met in MP, giving an optimal Lys:Met ratio of 3.0. Based on the NRC (2001) model, Lys supply was on average $6.7 \%$ of MP; supplementing with RPM in this study increased Met supply from 1.9 to $2.3 \%$ of MP and reduced the Lys:Met ratio from an average 3.5 to 2.9 (Table 4). This more favorable AA pattern may be expected to improve AA status and $\mathrm{N}$ utilization. Previously, we observed a mean increase of $35 \mathrm{~g} / \mathrm{d}$ of true protein with no significant interaction with dietary CP content - cows had similar mean response to RPM at both 15.8 and $17.1 \% \mathrm{CP}$ in the diet (Broderick et al., 2009). That the magnitude of the milk protein response to RPM in the earlier Latin square reversal study, with 4-wk periods, was similar to that obtained when RPM was fed continuously over 12 wk confirms the effectiveness of this supplement under normal feeding conditions. Supplementation with RPM has been shown to increase milk yield (Schmidt et al., 1999) and milk protein content (Armentano et al., 1997; Berthiaume et al., 2006) and yield (Armentano et al., 1997; Rulquin and Delaby, 1997). No effect of adding RPM to the diet was observed on nutrient digestibility in the current study.

Flows of MP and digested (metabolizable) Lys and Met, computed using the NRC (2001) model, were proportionate to DM intake and yielded mean estimates of, respectively, 2,027, 137, and $44 \mathrm{~g} / \mathrm{d}$ (bag), 2,105, 141, and $44 \mathrm{~g} / \mathrm{d}$ (bunker), and 2,212, 147, and $47 \mathrm{~g} / \mathrm{d}$ (oxygen-limited silo) (Table 4). Because DM intake was somewhat less than $24 \mathrm{~kg} / \mathrm{d}$ (Table 3), supplementation with RPM increased apparent metabolizable Met by 8 rather than $9 \mathrm{~g} / \mathrm{d}$. If the optimal concentrations of Lys and Met in MP are 7.2 and 2.4\% (NRC, 2001), then a "requirement" for these 2 essential AA may be computed using these proportions of the estimated MP supply. Estimated over the 6 diets, Lys supply ranged from 92 to $94 \%$ of requirement and Met supply averaged $79 \%$ of requirement without RPM and $97 \%$ of requirement with RPM addition (Table 4). Optimal ratio of metabolizable Lys to Met is reported to be about 3.0 (NRC, 2001); RPM supplementation decreased the Lys:Met ratio from 3.4 to 3.6 to 2.8-2.9 (Table 4). These computations suggest that Met limited production before RPM addition and Lys was probably limiting after RPM addition to the diets fed in this experiment. The response of fat secretion to RPM supplementation ranged from -13 to $65 \mathrm{~g} / \mathrm{d}$, with overall mean of only $17 \mathrm{~g} / \mathrm{d}(P=0.72$; Table 3$)$; previously we observed a mean increase of $79 \mathrm{~g} / \mathrm{d}$ with RPM addition to diets containing $21 \%$ AS with a greater proportion of dietary CP supplied by soybean meal (Broderick et al., 2009). However, overall mean true protein secretion increased $42 \mathrm{~g} / \mathrm{d}$, with range 25 to $73 \mathrm{~g} / \mathrm{d}$ (Table 4 ); mean recovery of Met-sulfur in milk Met and Cys was $22 \%$. Average response to similar levels of RPM supplementation in 2 Latin square trials was $37 \mathrm{~g}$ of protein/d with $17 \%$ Met recovery (Broderick et al., 2009) and $42 \mathrm{~g}$ of protein/d 
Table 3. Effect of storage structure used for dietary alfalfa silage and supplementation with rumen-protected Met (RPM) on production, excretion, and apparent digestibility in lactating dairy cows

\begin{tabular}{|c|c|c|c|c|c|c|c|c|c|}
\hline \multirow[b]{2}{*}{ Item } & \multicolumn{3}{|c|}{ Silo structure } & \multirow[b]{2}{*}{$\mathrm{SE}^{2}$} & \multirow[b]{2}{*}{$P>\mathrm{F}^{3}$} & \multicolumn{2}{|c|}{$\mathrm{RPM}^{1}{ }^{1} \mathrm{~g} / \mathrm{d}$} & \multirow[b]{2}{*}{$\mathrm{SE}^{2}$} & \multirow[b]{2}{*}{$P>\mathrm{F}$} \\
\hline & Bag & Bunker & $\mathrm{O}_{2}$-Limited & & & 0 & 8 & & \\
\hline \multicolumn{10}{|l|}{ Production } \\
\hline DM intake, $\mathrm{kg} / \mathrm{d}$ & $21.2^{\mathrm{b}}$ & $21.9^{\mathrm{b}}$ & $23.0^{\mathrm{a}}$ & 0.3 & $<0.01$ & 22.2 & 21.9 & 0.3 & 0.41 \\
\hline BW change, $\mathrm{kg} / \mathrm{d}$ & 0.09 & 0.09 & -0.01 & 0.08 & 0.63 & -0.02 & 0.13 & 0.07 & 0.12 \\
\hline Milk yield, kg/d & 36.6 & 36.9 & 37.5 & 0.7 & 0.63 & 36.5 & 37.4 & 0.6 & 0.25 \\
\hline Milk/DM intake & $1.74^{\mathrm{a}}$ & $1.69^{\mathrm{ab}}$ & $1.63^{\mathrm{b}}$ & 0.03 & 0.02 & 1.66 & 1.72 & 0.02 & 0.08 \\
\hline $3.5 \% \mathrm{FCM}, \mathrm{kg} / \mathrm{d}$ & 37.1 & 38.0 & 36.9 & 1.1 & 0.72 & 36.9 & 37.8 & 0.8 & 0.48 \\
\hline $\mathrm{SCC}, \times 10^{3}$ & 530 & 591 & 238 & 200 & 0.42 & 418 & 488 & 163 & 0.77 \\
\hline Milk fat, $\%$ & 3.67 & 3.86 & 3.50 & 0.11 & 0.07 & 3.72 & 3.63 & 0.09 & 0.48 \\
\hline Milk fat, $\mathrm{kg} / \mathrm{d}$ & 1.32 & 1.38 & 1.29 & 0.05 & 0.37 & 1.32 & 1.34 & 0.04 & 0.72 \\
\hline Milk true protein, $\%$ & 2.94 & 2.95 & 2.95 & 0.03 & 0.94 & 2.93 & 2.96 & 0.03 & 0.39 \\
\hline Milk true protein, $\mathrm{kg} / \mathrm{d}$ & 1.07 & 1.05 & 1.09 & 0.02 & 0.54 & 1.05 & 1.09 & 0.02 & 0.09 \\
\hline Milk lactose, $\%$ & 4.74 & 4.78 & 4.80 & 0.03 & 0.30 & 4.77 & 4.77 & 0.02 & 0.96 \\
\hline Milk lactose, $\mathrm{kg} / \mathrm{d}$ & 1.72 & 1.73 & 1.77 & 0.05 & 0.76 & 1.70 & 1.77 & 0.04 & 0.20 \\
\hline Milk SNF, \% & 8.57 & 8.61 & 8.65 & 0.03 & 0.19 & 8.58 & 8.64 & 0.02 & 0.11 \\
\hline Milk SNF, $\mathrm{kg} / \mathrm{d}$ & 3.11 & 3.10 & 3.18 & 0.07 & 0.70 & 3.06 & 3.19 & 0.06 & 0.14 \\
\hline MUN, mg/dL & $10.0^{\mathrm{b}}$ & $11.7^{\mathrm{a}}$ & $11.6^{\mathrm{a}}$ & 0.5 & 0.04 & 11.0 & 11.1 & 0.4 & 0.87 \\
\hline Milk-N/N intake, \% & 29.6 & 28.5 & 28.7 & 0.6 & 0.39 & 27.9 & 29.9 & 0.5 & 0.01 \\
\hline \multicolumn{10}{|l|}{ Excretion $^{4}$} \\
\hline Urine volume, $\mathrm{L} / \mathrm{d}$ & $20.6^{\mathrm{a}}$ & $21.3^{\mathrm{a}}$ & $15.3^{\mathrm{b}}$ & 1.3 & $<0.01$ & 19.1 & 19.1 & 1.0 & 1.00 \\
\hline Urine urea-N, g/d & $121^{\mathrm{b}}$ & $135^{\mathrm{a}}$ & $114^{\mathrm{b}}$ & 5 & 0.01 & 124 & 122 & 4 & 0.69 \\
\hline Total urine-N, g/d & $143^{\mathrm{b}}$ & $157^{\mathrm{a}}$ & $136^{\mathrm{b}}$ & 5 & 0.02 & 148 & 143 & 4 & 0.39 \\
\hline Urea- $\mathrm{N} /$ total urine- $\mathrm{N}, \%$ & 84.4 & 86.3 & 84.7 & 1.6 & 0.68 & 84.3 & 86.0 & 1.3 & 0.38 \\
\hline Fecal DM, kg/d & 9.2 & 9.0 & 9.1 & 0.3 & 0.88 & 9.3 & 9.0 & 0.2 & 0.43 \\
\hline Fecal N, g/d & 278 & 276 & 272 & 8 & 0.89 & 278 & 273 & 7 & 0.63 \\
\hline Manure-N, g/d & 420 & 434 & 408 & 11 & 0.26 & 425 & 416 & 9 & 0.44 \\
\hline N-balance, ${ }^{5} \mathrm{~g} / \mathrm{d}$ & $-4^{\mathrm{b}}$ & $-8^{\mathrm{b}}$ & $26^{\mathrm{a}}$ & 9 & 0.02 & 11 & -2 & 7 & 0.23 \\
\hline \multicolumn{10}{|l|}{ Apparent digestibility ${ }^{6}$} \\
\hline $\mathrm{DM}, \%$ & 57.6 & 59.2 & 60.2 & 0.8 & 0.09 & 59.1 & 58.9 & 0.7 & 0.83 \\
\hline OM, \% & 58.4 & 60.1 & 61.2 & 0.8 & 0.09 & 60.0 & 59.8 & 0.7 & 0.89 \\
\hline NDF, $\%$ & $37.3^{\mathrm{b}}$ & $40.4^{\mathrm{a}}$ & $41.0^{\mathrm{a}}$ & 0.9 & 0.02 & 39.7 & 39.5 & 0.7 & 0.86 \\
\hline $\mathrm{ADF}, \%$ & $40.7^{\mathrm{b}}$ & $40.9^{\mathrm{b}}$ & $43.6^{\mathrm{a}}$ & 0.8 & 0.04 & 41.6 & 41.9 & 0.7 & 0.75 \\
\hline $\mathrm{N}, \%$ & 52.3 & 52.9 & 55.4 & 1.1 & 0.14 & 53.9 & 53.1 & 0.9 & 0.56 \\
\hline
\end{tabular}

요

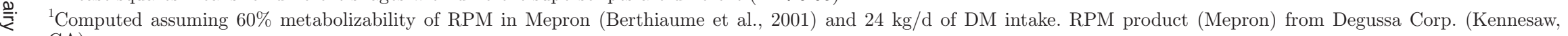
C) GA).

$\stackrel{\circ}{\frac{\Omega}{\Phi}}$ STtandard error of the least squares means.

ఠ్రి Probability of orthogonal contrasts for dietary source of alfalfa silage or supplementation with and without RPM.

$\delta \quad{ }^{4}$ Urinary excretion estimated using creatinine as a volume marker and fecal excretion estimated using indigestible ADF as an internal marker.

$\stackrel{5}{5}$ Nitrogen balance computed assuming milk protein contains $6.38 \% \mathrm{~N}$.

$\underset{ }{\sim} \quad{ }^{6}$ Apparent digestibilities estimated from spot fecal sampling, using indigestible ADF as an internal marker. 
Table 4. Estimated supply of MP and digested (metabolizable) AA and observed fat and protein yield responses to rumen-protected Met ${ }^{1}$ (RPM) supplementation of diets (at 0 or $8 \mathrm{~g} / \mathrm{d}$ ) based on alfalfa ensiled in bag, bunker, and oxygen-limited silos

\begin{tabular}{|c|c|c|c|c|c|c|}
\hline Item & \multicolumn{6}{|c|}{ Alfalfa silage source } \\
\hline DM intake, $\mathrm{kg} / \mathrm{d}$ & 21.6 & 20.7 & 22.3 & 21.6 & 22.7 & 23.4 \\
\hline \multicolumn{7}{|l|}{ Estimated supply ${ }^{2}$} \\
\hline $\mathrm{MP}, \mathrm{g} / \mathrm{d}$ & 2,069 & 1,985 & 2,140 & 2,070 & 2,180 & 2,244 \\
\hline Digested Lys, \% of MP & 6.75 & 6.75 & 6.70 & 6.70 & 6.65 & 6.65 \\
\hline Digested Met, $\%$ of MP & 1.92 & 2.40 & 1.87 & 2.32 & 1.93 & 2.26 \\
\hline Lys/Met ratio & 3.5 & 2.8 & 3.6 & 2.9 & 3.4 & 3.0 \\
\hline \multicolumn{7}{|l|}{ Estimated requirement ${ }^{3}$} \\
\hline Lys requirement, $\mathrm{g} / \mathrm{d}$ & 149 & 143 & 154 & 149 & 157 & 162 \\
\hline Met requirement, $\mathrm{g} / \mathrm{d}$ & 50 & 48 & 51 & 50 & 52 & 54 \\
\hline Lys supply, \% of requirement & 94 & 94 & 93 & 93 & 92 & 92 \\
\hline Response to RPM, g/d & & 25 & & 30 & & 73 \\
\hline RPM recovery, ${ }^{4} \%$ & & 13 & & 16 & & 36 \\
\hline
\end{tabular}

${ }^{1}$ Rumen-protected Met computed assuming 60\% metabolizability of RPM in Mepron (Berthiaume et al., 2001) and $24 \mathrm{~kg} / \mathrm{d}$ of DM intake. RPM product (Mepron) from Degussa Corp. (Kennesaw, GA).

${ }^{2}$ Digested (metabolizable) Met and Lys estimated using the NRC (2001) model based on observed DM intakes.

${ }^{3}$ Computed assuming digested (absorbed) Lys and Met required at, respectively, 7.2 and $2.4 \%$ of MP.

${ }^{4}$ Computed as recovery of RPM sulfur in milk assuming milk protein contained $2.7 \mathrm{~g}$ of Met and $1.3 \mathrm{~g}$ of Cys/100 g (NRC, 1982).

with 17\% Met recovery (Armentano et al., 1997). That numerically greater protein yield and recovery occurred in cows fed alfalfa from the oxygen-limited structure suggested that utilization of this higher quality $\mathrm{AS}$ with greater intake and fiber digestibility, and hence better energy status, was more limited by Met supply.

\section{CONCLUSIONS}

Chemical composition and digestibility of AS from an oxygen-limited silo indicated that there were lower fermentation losses from this silo, suggesting it would serve as a more effective structure for ensiling alfalfa than either bag or bunker silos. Losses of DM due to spoilage and as fermentation gases also were lowest from the oxygen-limited silo. However, production of milk and milk components was similar when diets formulated from these 3 alfalfa forages were fed continuously over a 12-wk experiment. Intake was greater on diets containing AS from the oxygen-limited silo and, because milk yield was not different, milk/DM intake was lower. Supplementing these diets with RPM to supply about $8 \mathrm{~g} / \mathrm{d}$ of absorbable Met tended to increase milk/ DM intake and true protein yield, and gave a highly significant improvement in $\mathrm{N}$ efficiency, compared with not feeding RPM. The magnitude of the increase in protein yield, $42 \mathrm{~g} / \mathrm{d}$, was comparable to the responses observed in previous reversal trials. These results indicate that diets formulated from high-quality $\mathrm{AS}$, corn silage, and high-moisture corn with supplemental soy protein are first-limiting in Met.

\section{ACKNOWLEDGMENTS}

The authors thank Rick Walgenbach and his farm crew for harvesting and storing the feedstuffs used in these trials and Jill Davidson and her barn crew for feeding and animal care at the US Dairy Forage Center Research Farm (Prairie du Sac, WI); Wendy Radloff, Mary Becker, Ursula Hymes-Fecht and Steven Diederich (US Dairy Forage Research Center) for assisting with sampling and laboratory analyses; and Peter Crump (University of Wisconsin-Madison) for assisting with statistical analyses. Partial financial support for this research from Engineered Stored Products Co. is also gratefully acknowledged.

\section{REFERENCES}

Armentano, L. E., S. J. Bertics, and G. A. Ducharme. 1997. Response of lactating cows to methionine or methionine plus lysine added to high protein diets based on alfalfa and heated soybeans. J. Dairy Sci. 80:1194-1199. 
Association of Official Analytical Chemists. 1980. Official Methods of Analysis. 13th ed. AOAC, Washington, DC.

Association of Official Analytical Chemists. 1990. Official Methods of Analysis. 15th ed. Association of Official Analytical Chemists, Arlington, VA.

Association of Official Analytical Chemists. 1997. Official Methods of Analysis. 16th ed. Association of Official Analytical Chemists, Arlington, VA.

Berthiaume, R., P. Dubreuil, M. Stevenson, B. W. McBride, and H. Lapierre. 2001. Intestinal disappearance and mesenteric and portal appearance of amino acids in dairy cows fed ruminally protected methionine. J. Dairy Sci. 84:194-203.

Berthiaume, R., M. C. Thivierge, R. A. Patton, P. Dubreuil, M. Stevenson, B. W. McBride, and H. Lapierre. 2006. Effect of ruminally protected methionine on splanchnic metabolism of amino acids in lactating dairy cows. J. Dairy Sci. 89:1621-1634.

Brito, A. F., and G. A. Broderick. 2007. Effects of feeding different protein supplements on milk production and nutrient utilization in dairy cows. J. Dairy Sci. 90:1816-1827.

Broderick, G. A. 1987. Determination of protein degradation rates using a rumen in-vitro system containing inhibitors of microbial nitrogen metabolism. Br. J. Nutr. 58:463-476.

Broderick, G. A. 1992. Relative value of fish meal versus solvent soybean meal for lactating dairy cows fed alfalfa silage as sole forage. J. Dairy Sci. 75:174-183.

Broderick, G. A. 1995. Desirable characteristics of forage legumes for improving protein utilization in ruminants. J. Anim. Sci. $73: 2760-2773$.

Broderick, G. A., and M. K. Clayton. 1997. A statistical evaluation of animal and nutritional factors influencing concentrations of milk urea nitrogen. J. Dairy Sci. 80:2964-2971.

Broderick, G. A., D. B. Ricker, and L. S. Driver. 1990. Expeller soybean meal and corn by-products versus solvent soybean meal for lactating dairy cows fed alfalfa silage as sole forage. J. Dairy Sci. $73: 453-462$

Broderick, G. A., M. J. Stevenson, and R. A. Patton. 2009. Effect of dietary protein concentration and degradability on response to rumen-protected methionine in lactating dairy cows. J. Dairy Sci. 92. In press.

Broderick, G. A., M. J. Stevenson, R. A. Patton, N. E. Lobos, and J. J. Olmos Colmenero. 2008. Effect of supplementing rumen-protected methionine on production and nitrogen excretion in lactating dairy cows. J. Dairy Sci. 91:1092-1102.

Broderick, G. A., P. Udén, M. L. Murphy, and A. Lapins. 2004. Sources of variation in rates of in vitro ruminal protein degradation. J. Dairy Sci. 87:1345-1359.

Cochran, R. C., D. C. Adams, J. D. Wallace, and M. L. Galyean. 1986. Predicting digestibility of different diets with internal markers: Evaluation of four potential markers. J. Anim. Sci. 63:14761487.

Faldet, M. A., and L. D. Satter. 1991. Feeding heat-treated full fat soybeans to cows in early lactation. J. Dairy Sci. 74:3047-3054.

Goering, H. K., and P. J. Van Soest. 1970. Forage Fiber Analyses (Apparatus, Reagents, Procedures, and Some Applications). Agric. Handbook No. 379. ARS-USDA, Washington, DC.

Hall, M. B., W. H. Hoover, J. P. Jennings, and T. K. M. Webster. 1999. A method for partitioning neutral detergent-soluble carbohydrates. J. Sci. Food Agric. 79:2079-2086.

Hintz, R. W., D. R. Mertens, and K. A. Albrecht. 1995. Effects of sodium sulfite on recovery and composition of detergent fiber and lignin. J. AOAC 78:16-22.
Huhtanen, P., K. Kaustell, and S. Jaakkola. 1994. The use of internal markers to predict total digestibility and duodenal flow of nutrients in cattle given six different diets. Anim. Feed Sci. Technol. 48:211-227.

Krizsan, S. J., G. A. Broderick, R. E. Muck, C. Promkot, S. Colombini, and $\AA$. T. Randby. 2007. Effect of alfalfa silage storage structure and roasting corn on production and ruminal metabolism of lactating dairy cows. J. Dairy Sci. 90:4793-4804.

Licitra, G., T. M. Hernandez, and P. J. Van Soest. 1996. Standardization of procedures for nitrogen fractionation of ruminant feeds. Anim. Feed Sci. Technol. 57:347-358.

McDonald, P., A. R. Henderson, and S. J. E. Heron. 1991. The Biochemistry of Silage. Chalcombe Publications, Marlow, UK.

Muck, R. E. 1987. Dry matter level effects on alfalfa silage quality. 1. Nitrogen transformations. Trans. ASAE 30:7-14.

Muck, R. E., and J. T. Dickerson. 1988. Storage temperature effects on proteolysis in alfalfa silage. Trans. ASAE 31:1005-1009.

Muck, R. E., and L. Kung Jr. 2007. Silage production. Pages 617-633 in Forages: The Science of Grassland Agriculture. Vol. II. 6th ed. R. F. Barnes, C. J. Nelson, K. J. Moore, and M. Collins, ed. Blackwell Publishing, Ames, IA.

Muck, R. E., L. E. Moser, and R. E. Pitt. 2003. Postharvest factors affecting ensiling. Pages 251-304 in Silage Science and Technology. D. R. Buxton, R. E. Muck, and J. H. Harrison, ed. American Society of Agronomy, Crop Science Society of America, Soil Science Society of America, Madison, WI.

Muck, R. E., and P. O'Kiely. 2002. New technologies for ensiling. Page 334 in Proc. XIIIth International Silage Conference, Auchincruive, Scotland.

Nagel, S. A., and G. A. Broderick. 1992. Effect of formic acid or formaldehyde treatment of alfalfa silage on nutrient utilization by dairy cows. J. Dairy Sci. 75:140-154.

National Research Council. 1982. United States-Canadian tables of feed composition. 3rd rev. ed. National Academy Press, Washington, DC

National Research Council. 2001. Nutrient Requirements of Dairy Cattle. 7th rev. ed. Natl. Acad. Sci., Washington, DC

Oser, B. L. 1965. Hawk's Physiological Chemistry. 14th ed. Blakiston, New York, NY.

Rulquin, H., and L. Delaby. 1997. Effects of the energy balance of dairy cows on lactational responses to rumen-protected methionine. J. Dairy Sci. 80:2513-2522.

SAS Institute. 1999-2000. SAS/STAT User's Guide. Release 8.1. SAS Inst. Inc., Cary, NC.

Schmidt, J., P. Sipocz, E. Cenkvari, and J. Sipocz. 1999. Use of protected methionine (Mepron M 85) in cattle. Acta Vet. Hung. 47:409-418.

Sniffen, C. J., J. D. O'Connor, P. J. Van Soest, D. G. Fox, and J. B. Russell. 1992. A net carbohydrate and protein system for evaluating cattle diets. 2. Carbohydrate and protein availability. J. Anim. Sci. 70:3562-3577.

Valadares, R. F. D., G. A. Broderick, S. C. Valadares Filho, and M. K. Clayton. 1999. Effect of replacing alfalfa silage with high moisture corn on ruminal protein synthesis estimated from excretion of total purine derivatives. J. Dairy Sci. 82:2686-2696.

Van Soest, P. J., J. B. Robertson, and B. A. Lewis. 1991. Methods for dietary fiber, neutral detergent fiber and nonstarch polysacharides in relation to animal nutrition. J. Dairy Sci. 74:3583-3597. 